ISSN 0258-7122

Bangladesh J. Agril. Res. 33(3) : 409-417, September 2008

\title{
CHANGE AND INSTABILITY IN AREA AND PRODUCTION OF WHEAT AND MAIZE IN BANGLADESH
}

\author{
M. N. HASAN $^{1}$, M. A. MONAYEM MIAH ${ }^{2}$, M. S. ISLAM ${ }^{3}$ \\ Q. M. ALAM ${ }^{4}$ AND M. I. HOSSAIN ${ }^{5}$
}

\begin{abstract}
The study measured the change and instability in area, production, and yield of two major cereal crops wheat and maize in Bangladesh based on secondary data during 1980/81-2003/04 using different statistical techniques. Area and production of wheat increased satisfactorily. But yield was not increased to meet the demand of the country. In the case of maize, significant increment happened in yield during the study period. Area and production of maize also increased to fulfill the increasing demand of population. Presently production of maize increased more rapidly than its area. The growth in area, production, and yield of wheat slightly improved in period-II, whereas the growth rate in area, production, and yield of maize improved rapidly. Though both of wheat and maize are unstable crops, maize showed very instability in its area and production because of its increasing tendency in the recent years.
\end{abstract}

Key Words: Change and instability, production, wheat, maize.

\section{Introduction}

Wheat, after rice is one the most important cereal crops in Bangladesh. It has versatile uses in making various human foods, such as bread, biscuits, cakes, sandwich, etc. But the production of wheat in the country is very insufficient to meet the increasing demand for food for the ever-increasing population. Bangladesh had to import a huge quantity of grain food, mainly wheat, to meet the deficit of cereals. In 1989/90 and 1990/91, the average supply of wheat was 2.35 million tons, of which 65\% was imported (Ahmed et al., 1996). In recent years, due attention has been given to wheat cultivation in Bangladesh. As a result, wheat acreage in this country has gradually been increased. Of course, there is real hope and bright possibility of' solving the crucial national food crisis by cultivating wheat.

\footnotetext{
${ }^{1}$ Lecturer, Statistics and Computer Science Department, BSMRAU, Salna, Gazipur-1706, ${ }^{2}$ Senior Scientific Officer, Agricultural Economics Division, BARI, Gazipur-1701, ${ }^{3}$ Senior Scientific Officer, Statistics Section, Agricultural Economics Division, BARI, Gazipur-1701, ${ }^{4}$ Chief Scientific Officer, Agricultural Economics Division, BARI, Gazipur-1701, ${ }^{5}$ Scientific Officer, Statistics Section, Agricultural Economics Division, BARI, Gazipur-1701, Bangladesh.
} 
Maize is an important food and feed crop being recognized relatively recently in Bangladesh and has gained an increasingly important attention by the government. It accounts for $18 \%$ of the world cereal acreage and about $25 \%$ of the world cereal production (Haque, 1999). This is mainly due to the huge demand of maize particularly for poultry feed industry. Besides maize has diversified uses as food and industrial raw materials. Demand for maize is likely to progressively increase in near future. At the present increasing rate of consumption, the demand for maize and it will exceed a million tons by 2012 (Iqbal, 2001).

The rate of increase in area, production, and yield of these two important cereal crops should be stable and steady. But in reality, instability exists in area, production, and yield of wheat and maize that needs to be studied. Therefore, it is very important to know the pattern of change and relationship between area and production of cereal crops in Bangladesh. The findings of this study provide some useful guidelines for the relevant researchers, policy makers and planners of the country.

\section{Objectives:}

(i) to determine the growth rate of area, production, and yield of wheat and maize.

(ii) to measure the change and instability in area, production, and yield of wheat and maize

(iii) to derive policy implications from the above objectives.

\section{Data and Analytical Procedures}

\section{Data and its sources}

Time series data on area, production, and yields of different cereal crops for 24 years from 1980/81 to 2003/04 were collected from different issues of the Statistical Yearbook of Bangladesh. The whole period was divided into two periods viz., period-I from 1980/81 to 1991/92 and period-II from 1992/93 to 2003/04 to compare in area, production, and yield between the two periods.

\section{Analytical procedures}

In order to examine the nature of change, instability, and degree of relationship in area, production, and yields of different cereal crops in Bangladesh, various statistical measures, such as mean, correlation co-efficient and co-efficient of variation were worked out. 
To identify the significant change in area, production, and yield between two periods, the following formula was used:

$$
t=\frac{\overline{x_{1}}-\overline{x_{2}}}{\sqrt{\frac{s_{1}^{2}}{n_{1}}+\frac{s_{2}^{2}}{n_{2}}}} ; \quad d f=\frac{\left(\frac{s_{1}^{2}}{n_{1}}+\frac{s_{2}^{2}}{n_{2}}\right)}{\frac{\left(s_{1}^{2} / n_{1}\right)^{2}}{n_{1}-1}+\frac{\left(s_{2}^{2} / n_{2}\right)^{2}}{n_{2}-1}}
$$

$\overline{x_{1}}=$ mean of the data of period I $s_{1}^{2}$-Variance of the data of period 1

$\overline{x_{2}}=$ mean of the data of period $2 \quad s_{2}^{2}$ - Variance of the data of period 2

$\mathrm{df}=$ degrees of freedom

The production of wheat and maize is likely to be influenced by the area used for wheat and maize in order to estimate the parameter; simple linear regression models were fitted to examine the change of production by the change of area. The model can be expressed as:

$Y=a+b X-e$

Where, $Y=$ Productionin in ton

$$
\begin{aligned}
& a=\text { Intercept }, b=\text { Regression coefficient } \\
& X=\text { Area in ha }
\end{aligned}
$$

The growth rates of area, production, and yield of maize and wheat were worked out by fitting a semi-log function of the following type:

$$
y=e^{a+b t} \text { or } I_{n} y=a+b t
$$

Where. $\mathrm{y}=$ Area (ha) or production (ton) or yield (t/ha)

$$
\mathrm{t}=\text { Time period (year) }
$$

An index of instability was computed for examining the nature and degree of instability in area, production, and yield in Bangladesh. The co-efficient of variation (CV) was worked out for area, production, and yield to measure of variability. However, simple CV does not explain properly the trend component inherent in the time series data. Alternatively, the Coefficient of variation around the trend $(\mathrm{CVt})$ rather than co-efficient of variation around the mean $(\mathrm{CV})$ was suggested by Cuddy and Della (1978) as a better measure of variability. 
A linear trend $y=a+b t+e$ was fitted to the indices of area, production and yield for the period 1 980/81-2003/04 and trend co-efficient "b" was tested for significance. Whenever the trend co-efficient was found significant, the index of instability was constructed as follows:

$C V_{t}=(C V) \times \sqrt{1-R^{2}}$

Where, $C V=\frac{\text { Standard deviation }}{\text { Mean }} \times 100$

In words, co-efficient of variation (CV) around the mean was multiplied by the square root of the proportion of the variation, which was unexplained by the trend equation, $y=a+b i+\mathrm{e}$.

\section{Results and Discussion}

Change in area, production and yield of wheat and maize over the periods:

Wheat has increased its importance during the past three decades as rising levels of imports (including large quantities of food aid) have led to a rapid increase in its consumption. In the wake of 1974 famine, the planted area of wheat had sharply increased (Chowdhury, 1993). Wheat area and production increased from period-I to period-Il significantly (at $1 \%$ level of significance). The increase in yield from period-I to period-II was also significant at $10 \%$ level of significance (Table 1). So the yield of wheat is not increased from period-I to period-II satisfactorily as with the enhancement of area.

Table 1. Change in area, production and yield of wheat and maize.

\begin{tabular}{|c|c|c|c|c|c|}
\hline \multirow{2}{*}{$\begin{array}{l}\text { Name of } \\
\text { crops }\end{array}$} & \multirow{2}{*}{$\begin{array}{c}\text { Field of } \\
\text { measurement }\end{array}$} & \multicolumn{2}{|c|}{ Mean Value } & \multirow[t]{2}{*}{ t-value } & \multirow{2}{*}{$\begin{array}{l}\mathrm{P}(\mathrm{T}<\mathrm{t}) \\
\text { two-tail }\end{array}$} \\
\hline & & $\begin{array}{c}\text { Period-I } \\
\text { 980/81-1991/93 }\end{array}$ & $\begin{array}{c}\text { Period-II } \\
(1992 / 93-2003 / 04)\end{array}$ & & \\
\hline \multirow{3}{*}{ Whet } & Area (ha) & $5,74,837$ & $7,23,848 * * *$ & -5.387 & 0.000 \\
\hline & Production (Ton) & $10,78,557$ & $14,97,105^{* * *}$ & -4.736 & 0.000 \\
\hline & Yield (t/ha) & 1.876 & $2.068 *$ & -2.355 & 0.029 \\
\hline \multirow{3}{*}{ Maize } & & 2,967 & 10,516 & -1.729 & 0.111 \\
\hline & & 2,537 & 38,055 & -1.680 & 0.121 \\
\hline & & 0.854 & $3.619 * *$ & -2.627 & 0.015 \\
\hline
\end{tabular}

Note: '***' and '**' represent significant at $1 \%$ and $5 \%$ level

In the last two decades, the area of maize has increased by more than three times, while its production has increased by 15 times. The average area of wheat in periodI was $5,74,837$ ha, whereas it was 7,23,848 ha in period-II. The change between these two periods is highly insignificant at $1 \%$ level. The mean difference between 
the two maize production levels in two periods was insignificant. But the average yield of maize in period-II increased significantly at 5\% level from period-I.

\section{Correlation test}

A commonly employed method for measuring the changing attitude of area and production of any crop is correlation. This procedure built on the rationale that if area influencing the production the numerical evidence of this relationship is in Table 2. The correlation coefficient (r) of area and production of wheat for whole period is 0.943 , which is highly significant at $1 \%$ level implying that the increment of area strongly affect the production of wheat to increase. The wheat production in period-I was not increased significantly as the value of ' $r$ ' is 0.498 . The relationship between area and production of wheat in period-Il is very much strong $(r=0.985)$ and significant at $1 \%$ level.

In the case of maize, the relationships between area and production in all the periods considered in this study are very strong and significant at $1 \%$ level. It implies that the production of maize has increased due to increase in its area.

Table 2. Relationship between area and production of wheat and maize

\begin{tabular}{c|l|l|l|l}
\hline Name of crops & Criteria & \multicolumn{2}{|l|}{ Value of Correlation $(\mathrm{r})$} & $\mathrm{P}(\mathrm{T}<\mathrm{t})$ two-tail \\
\hline \multirow{3}{*}{ Wheat } & \multirow{3}{*}{ Area Vs production } & Whole period & $0.943^{* * *}$ & 0.000 \\
\cline { 3 - 5 } & & Period-I & 0.498 & 0.100 \\
\cline { 3 - 5 } & & Period-II & $0.985^{* * *}$ & 0.000 \\
\hline \multirow{3}{*}{ Maize } & \multirow{3}{*}{ Area Vs production } & Whole period & $0.994 * * *$ & 0.000 \\
\cline { 3 - 5 } & & Period-I & $0.922^{* * *}$ & 0.000 \\
\cline { 3 - 5 } & & Period-II & $0.994 * * *$ & 0.000 \\
\hline
\end{tabular}

Note: '***' and '*' represent significant at $1 \%$ and $10 \%$ level

\section{Regression analysis}

The simple linear regression functions were fitted for estimating the response of production of wheat and maize due to the change of their respective area. Production of wheat was significantly increased by 1.138 and 1.259 times during the whole study period and period 1, respectively, by unit change in area. In the case of period-I, the production of wheat was not significantly increased as the co-efficient of production on area was found to be 0.67 .

In the case of maize, the estimated co-efficient of production on area are significant at $1 \%$ level of significance during all the periods. It implies that the production of maize increased by 1.94. 0.48 and 1.95 times during whole period, period-I and period-II due to increase in a unit area, respectively. So, an increasing tend is found in maize production with the increase in its area expansion. 
Table 3. Testing dependency of production on area.

\begin{tabular}{c|l|l|l|l|l}
\hline $\begin{array}{c}\text { Name of } \\
\text { crops }\end{array}$ & \multicolumn{1}{|c|}{ Period } & \multicolumn{1}{|c|}{$\begin{array}{c}\text { Constant } \\
\text { value }\end{array}$} & $\begin{array}{c}\text { Regression } \\
\text { Coefficients }\end{array}$ & \multicolumn{1}{|c|}{ t-value } & $\begin{array}{c}\mathrm{P}(\mathrm{T}<=\mathrm{t}) \text { two } \\
\text { tail }\end{array}$ \\
\hline \multirow{3}{*}{ Wheat } & Whole period & -537753.22 & $1.138^{* * *}$ & 13.2958 & 0.000 \\
\cline { 2 - 6 } & Period-I & 123961.34 & 0.672 & 1.815 & 0.100 \\
\cline { 2 - 6 } & Period-II & -754086.02 & $1.259 * * *$ & 18.052 & 0.000 \\
\hline \multirow{3}{*}{ Maize } & Whole period & -12069.32 & $1.943^{* * *}$ & 43.435 & 0.000 \\
\cline { 2 - 6 } & Period-I & -982.57 & $0.480^{* * *}$ & 7.557 & 0.000 \\
\cline { 2 - 6 } & Period-II & -12648.39 & $1.952 * * *$ & 29.192 & 0.000 \\
\hline
\end{tabular}

Note: '***' and '*' represent significant at $1 \%$ and $10 \%$ level

\section{Growth rate in area, production, and yield}

The growth rates of area, production, and yield for wheat and maize during periodI, period-II, and whole period are presented in Table 4. The growth rates of area and production for wheat are positive and highly significant at $1 \%$ level during the whole period. In the case of yield of wheat, the growth rates during whole period and period-Il are positive and significant at $10 \%$ and $5 \%$ levels, respectively. In the case of maize, the growth rates of area, production, and yield are positive and highly significant at $1 \%$ level during all the periods except period-I.

Table 4. Growth rates of area, production and yield of wheat and maize.

\begin{tabular}{|c|c|c|c|c|}
\hline Name of Crops & $\begin{array}{c}\text { Field of } \\
\text { Measurement }\end{array}$ & $\begin{array}{c}\text { Measurement } \\
\text { Statistics }\end{array}$ & $\begin{array}{c}\text { Growth Rate } \\
(\%)\end{array}$ & $\begin{array}{c}\mathrm{P}(\mathrm{T}<=\mathrm{t}) \text { two } \\
\text { tail }\end{array}$ \\
\hline \multirow{9}{*}{ Whet } & \multirow{3}{*}{ Area } & Whole period & $1.641 * * *$ & 0.000 \\
\hline & & Period-I & 0.580 & 0.370 \\
\hline & & Period-II & 1.201 & 0.124 \\
\hline & \multirow{3}{*}{ Production } & Whole period & $2.182 * * *$ & 0.000 \\
\hline & & Period-I & -0.970 & 0.374 \\
\hline & & Period-II & 2.389 & 0.119 \\
\hline & \multirow{3}{*}{ Yield } & Whole period & 0.541 & 0.078 \\
\hline & & Period-I & -1.459 & 0.107 \\
\hline & & Period-II & $1.188^{*}$ & 0.035 \\
\hline \multirow{9}{*}{ Maize } & \multirow{3}{*}{ Area } & Whole period & $7.382 * * *$ & 0.001 \\
\hline & & Period-I & 3.975 & 0.086 \\
\hline & & Period-II & $24.575 * * *$ & 0.086 \\
\hline & \multirow{3}{*}{ Production } & Whole period & $14.128 * * *$ & 0.000 \\
\hline & & Period-I & $10.234^{* *}$ & 0.000 \\
\hline & & Period-II & $39.635 * * *$ & 0.001 \\
\hline & \multirow{3}{*}{ Yield } & Whole period & $6.746 * * *$ & 0.000 \\
\hline & & Period-I & $6.259 * * *$ & 0.000 \\
\hline & & Period-II & $15.059 * * *$ & 0.000 \\
\hline
\end{tabular}

Note: ‘***’; ‘*’ represent significant at $1 \%, 5 \%$ and $10 \%$ level 


\section{Instability in area, production and yield of wheat and maize}

Fluctuation in area and production of wheat and maize are interrelated as wider area gives greater production if the inputs remain constant. But variation in yield may be due to weather condition, technological changes, etc. The instability of wheat and maize in area. production and yield are shown in Table 5.

Table 5. Instability in area, production and yield of wheat and maize.

\begin{tabular}{|c|c|c|c|c|c|}
\hline $\begin{array}{l}\text { Name of } \\
\text { crops }\end{array}$ & $\begin{array}{c}\text { Field of } \\
\text { Measurement }\end{array}$ & Measurement statistics & $\begin{array}{l}\text { Whole } \\
\text { period }\end{array}$ & Period-I & Period-II \\
\hline \multirow{15}{*}{ Wheat } & \multirow{5}{*}{ Area } & $\mathrm{CV}$ & $15.54 \%$ & 7.522 & 11.812 \\
\hline & & R-square & 0.569 & 0.067 & 0.126 \\
\hline & & $\mathrm{P}(\mathrm{T}<=\mathrm{t})$ two-tail & $0.000 * * *$ & 0.415 & 0.258 \\
\hline & & $\mathrm{D}-\mathrm{W}$ & 1.008 & 2.576 & 0.463 \\
\hline & & $\mathrm{CV}$ around trend line & 10.202 & - & - \\
\hline & \multirow{5}{*}{ Production } & $\mathrm{CV}$ & $23.360 \%$ & 13.373 & 18.032 \\
\hline & & R-square & 0.465 & 0.074 & 0.199 \\
\hline & & $\mathrm{P}(\mathrm{T}<=\mathrm{t})$ two-tail & $0.000 * * *$ & 0.394 & 0.146 \\
\hline & & $\mathrm{D}-\mathrm{W}$ & 0.623 & 1.517 & 0.454 \\
\hline & & $\mathrm{CV}$ around trend line & 17.087 & - & - \\
\hline & \multirow{5}{*}{ Yield } & $\mathrm{CV}$ & $10.208 \%$ & $11.538 \%$ & $6.938 \%$ \\
\hline & & R-square & 0.134 & 0.231 & 0.361 \\
\hline & & $\mathrm{P}(\mathrm{T}<=\mathrm{t})$ two-tail & 0.078 & 0.114 & $0.039 *$ \\
\hline & & $\mathrm{D}-\mathrm{W}$ & 0.651 & 1.096 & 0.737 \\
\hline & & $\mathrm{CV}$ around trend line & 9.199 & - & 5.544 \\
\hline \multirow{15}{*}{ Maize } & \multirow{5}{*}{ Area } & $\mathrm{CV}$ & $165.263 \%$ & 24.735 & 143.590 \\
\hline & & R-square & 0.305 & 1.98 & 0.552 \\
\hline & & $\mathrm{P}(\mathrm{T}<=\mathrm{t})$ two-tail & $0.005 * * *$ & 0.147 & $0.006 * *$ \\
\hline & & $\mathrm{D}-\mathrm{W}$ & 0.326 & 1.522 & 0.421 \\
\hline & & $\mathrm{CV}$ around trend line & 137.774 & - & 96.108 \\
\hline & \multirow{5}{*}{ Production } & $\mathrm{CV}$ & $265.073 \%$ & 37.199 & 192.434 \\
\hline & & R-square & 0.282 & 0.503 & 0.506 \\
\hline & & $\mathrm{P}(\mathrm{T}<=\mathrm{t})$ two-tail & $0.008 * *$ & $0.010 * *$ & $0.01 * *$ \\
\hline & & $\mathrm{D}-\mathrm{W}$ & 0.257 & 0.945 & 0.365 \\
\hline & & $\mathrm{CV}$ around trend line & 224.6029 & 26.225 & 135.25 \\
\hline & \multirow{5}{*}{ Yield } & $\mathrm{CV}$ & $81.431 \%$ & 22.737 & 73.249 \\
\hline & & R-square & 0.513 & 0.77 & 0.708 \\
\hline & & $\mathrm{P}(\mathrm{T}<=\mathrm{t})$ two-tail & $0.000 * * *$ & $0.000^{* * *}$ & $0.001^{* * *}$ \\
\hline & & $\mathrm{D}-\mathrm{W}$ & 0.2511 & 0.428 & 0.339 \\
\hline & & CV around trend line & 56.828 & 10.904 & 39.589 \\
\hline
\end{tabular}

Note: '***' and '*' represent significant at $1 \%$ and $10 \%$ level

The area and production of wheat during the whole period experienced the highest degree of instability, which is significant at $1 \%$ level. Yield of wheat during whole period is significantly fluctuated at $10 \%$ level. 
Area of maize during the whole period shows highest degree of instability. Production during whole period and period-II reflect higher degree of instability at the same time yield also shows remarkable degree of instability during these two periods.

\section{Conclusion and Recommendation}

Overall condition of wheat production in Bangladesh is not satisfactory during the study period. Since remarkable increment in average area and production of wheat witnessed during period-II, but in case of yield, there happened a little increment to meet the increasing demand of the country. Trend line for area and production of wheat also give evidence in favour of the above statement. During period-II, area is strongly influenced its production, but in period-I, the relationship is weak. In period-II, wheat production shows a slight upward tendency. Therefore, scientists should give more attention to develop sustainable variety in unfavourable weather to meet the increasing demand. If we fail to provide farmers, weather suitable and high yielding variety, the rate of import of wheat must be increased.

The overall trend of maize production in Bangladesh is quite satisfactory. The average yield of maize is double in period-Il compared to period-I. Examination of correlation and regression analysis also shows that production of maize increase nearly 2 times with unit increase in area. The trend line for maize also gives the evidence on behalf of increasing tendency of area and production of maize. Growth rate in production and yield of maize is greater than growth rate in area. Thus maize production in Bangladesh has bright future to meet the increasing demand.

Through the production trend of maize in Bangladesh is satisfactory, a huge amount of maize has to be imported from foreign countries every year. Therefore, researchers, policy makers, and farmers should give more attention to increase maize production.

\section{References}

Ahmed, S. M. and C. A. Meisner. 1996. Wheat Research and Development in Bangladesh. Publisher: Bangladesh Australia Wheat Improvement Project and CYMMYT- Bangladesh, Dhaka. First Edition. p. 201.

Chowdury, N. 1993. The Structure and Conduct of Bangladesh's Wheat Market: Some Ernerging Insights, Dhaka: IFPTI/BFPP.

Coddy and Della Valle. 1978. Measuring the Instability of Time Series Data. Oxford Bulletin of Economics and Statistics, February, 1978. 
Gujrati. D. N. 1998. Basic Econometrics. Publisher: McGraw-Hill, Inc., New York. Third Edition. p. 838.

Gupta, S. C. and V. K. Kapoor (Eight Edition, 1983, Reprint, 1993): Fundamentals of Mathematical Statistics. Publisher: Sultan Chand \& Sons, New Delhi, Eighth Edition. p. 1.1-16.71.

Haque, A.B.M.M. 1996. An Agribusiness Study on Winter Maize System in Some Selected Areas of Bangladesh. Unpublished M.Sc Thesis, Department of Cooperation and Marketing, Bangladesh Agricultural University, Mymensingh.

Iqbal. J. 2001. Exploiting potentials of maize in Bangladesh. National workshop on "Evolving Maize Industry Development in Bangladesh" held on June 2001 at BARC, Dhaka, Bangladesh.

\section{Appendix Table}

\begin{tabular}{c|c|c|c|c|c|c}
\hline & \multicolumn{3}{|c|}{ Wheat } & \multicolumn{3}{c}{ Maize } \\
\cline { 2 - 7 } Year & $\begin{array}{c}\text { Area } \\
\text { (acre) }\end{array}$ & $\begin{array}{c}\text { Production } \\
\text { (ton) }\end{array}$ & $\begin{array}{c}\text { Yield } \\
\text { (t/acre) }\end{array}$ & $\begin{array}{c}\text { Area } \\
\text { (acre) }\end{array}$ & $\begin{array}{c}\text { Production } \\
\text { (ton) }\end{array}$ & $\begin{array}{c}\text { Yield } \\
\text { (t/acre) }\end{array}$ \\
\hline $1980-81$ & 1460910 & 1075255 & 0.73602 & 5000 & 1000 & 0.20000 \\
$1981-82$ & 1319735 & 952110 & 0.72144 & 5000 & 1000 & 0.20000 \\
$1982-83$ & 1283445 & 1078070 & 0.83998 & 4000 & 1000 & 0.25000 \\
$1983-84$ & 1299755 & 1211501 & 0.93210 & 10139 & 3118 & 0.30752 \\
$1984-85$ & 1670765 & 1463630 & 0.87602 & 9321 & 3270 & 0.35082 \\
$1985-86$ & 1335140 & 1041825 & 0.78031 & 7803 & 2920 & 0.37421 \\
$1986-87$ & 1445000 & 1090990 & 0.75501 & 7666 & 2934 & 0.38272 \\
$1987-88$ & 1476290 & 1048015 & 0.70989 & 7579 & 2855 & 0.37669 \\
$1988-89$ & 1384030 & 1021950 & 0.73839 & 8324 & 3229 & 0.38791 \\
$1989-90$ & 1463060 & 890000 & 0.60831 & 8265 & 3350 & 0.40532 \\
$1990-91$ & 1480050 & 1004290 & 0.67855 & 7680 & 3040 & 0.39583 \\
$1991-92$ & 1419990 & 1065050 & 0.75004 & 7225 & 2725 & 0.37716 \\
$1992-93$ & 1573930 & 1175630 & 0.74694 & 7200 & 2725 & 0.37847 \\
$1993-94$ & 1520120 & 1131050 & 0.74405 & 6710 & 2785 & 0.41505 \\
$1994-95$ & 1580030 & 1244990 & 0.78795 & 6700 & 2680 & 0.40012 \\
$1995-96$ & 1732430 & 1369130 & 0.79029 & 6550 & 2675 & 0.40839 \\
$1996-97$ & 1749080 & 1454100 & 0.83135 & 6570 & 2695 & 0.41019 \\
$1997-98$ & 1988420 & 1802815 & 0.90665 & 6295 & 2650 & 0.42096 \\
$1998-99$ & 2179640 & 1908435 & 0.87557 & 6955 & 2970 & 0.42703 \\
$1999-00$ & 2056950 & 1839980 & 0.89451 & 7810 & 4075 & 0.52176 \\
$2000-01$ & 1909290 & 1673280 & 0.87638 & 12130 & 10350 & 0.85325 \\
$2001-02$ & 1833110 & 1605760 & 0.87597 & 49350 & 64335 & L30364 \\
$2002-03$ & 1745750 & 1506710 & 0.86307 & 71805 & 117255 & 1.63296 \\
$2003-04$ & 1586110 & 1253380 & 0.79022 & 123625 & 241460 & 195316 \\
\hline
\end{tabular}

